\title{
Cancer stem cells and tumorigenesis
}

\author{
Pingping Zhu' ${ }^{1}$, Zusen Fan ${ }^{1,2} \bowtie$ \\ ${ }^{1}$ CAS Key Laboratory of Infection and Immunity, CAS Center for Excellence in Biomacromolecules, Institute of \\ Biophysics, Chinese Academy of Sciences, Beijing 100101, China \\ ${ }^{2}$ University of Chinese Academy of Sciences, Beijing 100049, China
}

Received: 1 June 2018 / Accepted: 16 July 2018 / Published online: 29 August 2018

\begin{abstract}
Cancer is one of the most serious diseases all over the world, and the cancer stem cell (CSC) model accounts for tumor initiation, metastasis, drug resistance, and relapse. The CSCs within tumor bulk have the capacity to self-renew, differentiate, and give rise to a new tumor. The self-renewal of CSCs is precisely regulated by various modulators, including Wnt/ $\beta$-catenin signaling, Notch signaling, Hedgehog signaling, transcription factors, chromatin remodeling complexes, and non-coding RNAs. CSCs reside in their niches that are also involved in the self-renewal maintenance of CSCs and protection of CSCs from chemotherapy, radiotherapy, and even endogenous damages. Moreover, CSCs can also remodel their niches to initiate tumorigenesis. The mutual interactions between CSCs and their niches play a critical role in the regulation of CSC self-renewal and tumorigenesis as well. Many surface markers of CSCs have been identified, and these markers become first choices for CSC targeting. Due to heterogeneity and plasticity, targeting CSCs is still a big challenge for tumor elimination. In this review, we summarize recent progresses on the biological features of CSCs and targeting strategies against CSCs.
\end{abstract}

Keywords Cancer stem cells, Self-renewal, Signaling pathway, Tumorigenesis, Intervention

\section{HISTORY OF THE CANCER STEM CELL MODEL}

Cancer is a leading killer of human health, and more than 10 million patients die of cancer every year (McGuire 2016). Although many tumorous hypotheses and intervention strategies have been revealed, however, the real mechanism of tumor initiation is still elusive. The cancer stem cell (CSC) model fits well with tumor initiation, metastasis, drug resistance, and relapse, which is supported by more and more experimental and clinical data. At present, the CSC model has been accepted by many researchers and clinicians, and will become a promising strategy for tumor intervention in the near future (Shabbir et al. 2018; Takebe et al. 2011, 2015).

$\varangle$ Correspondence: fanz@moon.ibp.ac.cn (Z. Fan)
Actually, the concept of CSC model was raised a long time ago. Based on the similarity between cancer and the embryo, Lobstein and Recamier raised an embryonic origin of tumor model in 1829. They thought that tumor originated from proliferating embryonic cells that persisted in adulthood (Krebs 1947). Although this hypothesis fits well with many clinical observations, this hypothesis has not been proved because of technical limitations.

The CSC model was proved for the first time in 1991 in leukemia patients. There are several kinds of leukemia cells, including $\mathrm{CD}^{-} 4^{+} \mathrm{CD}_{3}{ }^{-}$cells and $\mathrm{CD} 4^{-} \mathrm{CD} 8^{+}$cells. $\mathrm{CD} 4^{+} \mathrm{CD}^{-} 8^{-}$cells can initiate leukemia efficiently, but $\mathrm{CD} 34^{-} \mathrm{CD} 38^{+}$cells cannot, showing the existence of leukemia stem cells (Terstappen et al. 1991). Later on, using various tumor models, scientists then found that all the cells in tumor bulk cannot propagate efficiently and only a small subset of tumor cells can initiate new tumors (Shigdar et al. 2012). A 
bunch of surface markers of cancer stem cells have been identified, and CSCs have been identified in many solid tumors up to date (Gopalan et al. 2018).

Tumors originate from the CSCs, but what is the origin of CSCs? Several hypotheses have been raised: (1) CSCs are transformed form of differentiated somatic cells; (2) Mutations are accumulated in normal tissue progenitor cells to form CSCs; (3) CSCs originate from dedifferentiation of normal tumor cells. Lineage tracing and single-cell sequencing are good tools to investigate the origin of CSCs. Lineage tracing data by several groups showed that colorectal CSCs are derived from Lgr5 $^{+}$intestinal stem cells (Barker et al. 2009; Melo et al. 2017; Schepers et al. 2012; Shimokawa et al. 2017). Taking advantage of single-cell sequencing of bladder CSCs, non-stem tumor cells, and normal bladder cells, Fan lab concluded the multiple sources of bladder CSCs (Yang et al. 2017). Single-cell analysis also revealed the heterogeneity of liver CSCs (Zheng et al. 2018).

The tumorigenesis models contain the hierarchical models and the stochastic model. Tumors originate from certain cells according to the hierarchical model; whereas the stochastic model assumes that any cells may initiate tumors as a result of mutation or other oncogenic factors (Quail et al. 2012). Both models were proved by massive experimental and clinical data, which largely confuse the understanding of tumorigenesis. The standard CSC model belongs to the hierarchical model. According to the classical CSC model, tumors are formed as the result of CSC differentiation, and non-CSCs die of clonal exhaustion (Greaves 2013). However, dedifferentiation occurs in some differentiated epithelial cells to form CSCs, and the dedifferentiation can be hierarchical or stochastic (Chaffer and Weinberg 2015). In liver CSCs, Yap1 activation is prerequisite for self-renewal and cell-fate determination. Yap1 deficiency in liver CSCs can convert them into non-CSCs, and differentiated liver cancer cells became liver CSCs when Yap1 is enforcedly overexpressed (Zhu et al. 2016b). The cellfate switch between CSCs and non-CSCs confirms the plasticity of CSCs, which may combine the hierarchical and stochastic tumorigenesis models together.

\section{BIOLOGICAL CHARACTERISTICS AND STUDY STRATEGIES OF CSCS}

The CSCs within tumor bulk display the capacity to selfrenew, differentiate, and give rise to a new tumor (Visvader and Lindeman 2012). Recently, lots of surface markers of CSCs have been identified, including CD133, CD13, CD24, ALDH1A1, CD44, and so on (Henderson et al. 2018; Li et al. 2018; Marotta et al. 2011; OrganistaNava et al. 2014; Yang et al. 2014). It is still a general strategy to isolate CSCs by FACS and to examine their biological features. There are usually more than one surface marker of CSCs that have been found in a certain tumor, indicating the heterogeneity within CSCs (Haraguchi et al. 2010; Yang et al. 2008b). The heterogeneity of liver CSCs was proved by single-cell sequencing (Zheng et al. 2018). Combination of different markers may be a better strategy for CSC enrichment. Fan lab revealed that $\mathrm{CD} 133^{+} \mathrm{CD} 13^{+}$liver $\mathrm{CSCs}$ have much stronger self-renewal and tumorigenesis capacities than $\mathrm{CD}_{133^{+}} \mathrm{CSCs}$ or $\mathrm{CD} 13^{+}$CSCs alone (Wang et al. 2015).

CSCs, also termed as tumor initiating cells (TICs), are the predominant cells for tumor initiation $\left(\mathrm{O}^{\prime} \mathrm{Brien}\right.$ et al. 2007). Accordingly, the tumor initiation assay is a standard and well-accepted method to examine the selfrenewal of CSCs (Hermann et al. 2007). Gradient numbers of cells are used for tumor observations, and the ratios of CSCs are calculated by extreme limiting dilution analysis (Zhu et al. 2015a, b). The sphere formation is another widely used method for CSC detection (Cao et al. 2011). In FBS-free medium and ultra-low adherent plates, normal tumor cells die of anoikis, while CSCs can escape from anoikis and propagate into oncospheres. CSCs from many tumor types can generate oncospheres, including breast cancer, liver cancer, colorectal cancer, bladder cancer, and so on (Cao et al. 2011; Ponti et al. 2005; Ricci-Vitiani et al. 2007; Yang et al. 2017). The side population is another assay for CSCs. As we know, CSCs play a critical role in drug resistance (Dean et al. 2005). Highly expressed many drug-pump molecules such as ABCG2 and CSCs can pump intracellular drugs out of cells to escape drug-induced cytotoxicity. During withdrawal of drugs, survived CSCs can propagate and differentiate into a new tumor, which is termed "tumor relapse" (Merlos-Suarez et al. 2011). Taking advantage of this characteristic, researchers developed the side population assay to detect CSCs (Chiba et al. 2006).

Recently, several new strategies for CSC study have been established. Genetic lineage tracing is an important tool to examine the self-renewal of CSCs in vivo (Meacham and Morrison 2013). Lgr5 and OLFM4 tracing proved that colorectal cancer originated from Lgr5 ${ }^{+}$ intestinal stem cells (Barker et al. 2009, 2007; Schepers et al. 2012; Van der Flier et al. 2009). As we know, almost all surface markers of CSCs are also markers of normal tissue stem cells, and CSC-targeted intervention probably blocks tissue hemostasis and renewal. Therefore, it is an urgent issue to identify CSC-specific markers. Two-dimensional mass spectrometry and single-cell RNA sequencing are ideal methods to identify novel markers of CSCs (Zheng et al. 2018). It also made 
sense to deliver CSC-targeting reagents with nanoparticles, which are majorly distributed in tumors due to enhanced permeability and retention (EPR) effects (Gao et al. 2004; Schroeder et al. 2012; Sun et al. 2014). By delivering gene or drugs, some smart and environmentresponse nanoparticles also emerge as good carriers in CSC targeting (Schroeder et al. 2012; Sun et al. 2014).

\section{SIGNALING PATHWAYS FOR CSCS}

The self-renewal of CSCs is maintained under precise regulation, and there are several major signaling pathways in the CSC regulation, including Wnt/ $\beta$-catenin, Notch, and Hedgehog signaling pathways. The Wnt/ $\beta$-catenin signaling plays a critical role in many physiological and pathological processes, including development, organ formation, and tumorigenesis (Clevers 2006). As the most important signaling in the regulation of the self-renewal of CSCs, Wnt/ $\beta$-catenin signaling is activated by $\beta$-catenin and TCF, leading to expression of target genes, containing c-MYC, CCND1/2, Axin2, SOX4, TCF7, ASCL2, LGR5, and so on (MacDonald et al. 2009). When the Wnt signaling is OFF, $\beta$-catenin is located in the cytoplasm and form the APC-degrading complex (Wu et al. 2003). When the Wnt signaling is ON, the APCdegrading complex is disrupted and $\beta$-catenin translocates into the nucleus, where it associates with TCF/LEF to form the $\beta$-catenin-activating complex (Korinek et al. 1997). Many inhibitors of the Wnt/ $\beta$-catenin pathway have been used for intervention of CSCs.

The Notch signaling, another critical modulator for development, also regulates CSC self-renewal (Kopan and Ilagan 2009). When engaged with Notch ligands (DLL1-4), Notch receptors are cleaved by $\gamma$-secretase into a stable intracellular domain (NICD), which can translocate into the nucleus and activate the transcription of Notch target genes, including HES family genes, HEY family genes, NRARP, and so on (Mumm and Kopan 2000). Of note, the roles of Notch signaling in CSC selfrenewal are controversial, depending on cancer types and Notch receptors. Fan lab showed that in liver CSCs, NOTCH2 is a predominant NOTCH receptor. NOTCH2 is highly expressed in liver CSCs and plays a critical role in the self-renewal maintenance of liver CSCs (Zhu et al. 2015b).

The Hedgehog signaling drives progress of basal cell carcinoma, bladder cancer, and other tumors (Li et al. 2016; Takebe et al. 2011). The activation of Hedgehog signaling is controlled by two receptors, Patched and Smo. The Patched receptor inhibits the activation of Hedgehog pathway and the Smo receptor plays an opposite role. Once engaged with ligands (shh, ihh, dhh), the inhibition of Patched is relieved and Smo is activated, and Hedgehog target genes are consequently expressed (Katoh and Katoh 2006). Similar with Wnt/ $\beta$ catenin and Notch signaling pathways, the Hedgehog activation is also well regulated. For instance, GALNT1, a glycotransferase highly expressed in $\mathrm{BCMab}^{+} \mathrm{CD} 44^{+}$ bladder CSCs, can activate Hedgehog signaling through O-linked glycosylation of SHH and promote the selfrenewal of bladder CSCs (Li et al. 2016).

Besides Wnt $/ \beta$-catenin, Notch, and Hedgehog signaling pathways, other signaling pathways are also involved in the self-renewal of certain tumors. For example, lung CSCs secrete CSF and c-Kit to drive their self-renewal through an autocrine manner (Levina et al. 2010). PTEN pathway plays a critical role in the selfrenewal regulation of esophageal CSCs and breast CSCs (Li et al. 2011; Zhou et al. 2007). Yap1 and Rspo are predominant modulators for colorectal CSCs (Barry et al. 2013). In addition, Yap1 signaling modulates the cell-fate and plasticity of liver CSCs (Zhu et al. 2016b).

\section{GENETIC AND EPIGENETIC REGULATION OF CSCS}

Accumulating evidence shows that many genetic and epigenetic factors are involved in the regulation CSC self-renewal. As we know, transcription factors (TFs) are critical modulators in cell-fate determination. Oct4, c-Myc, Nanog, and Klf4 overexpression can convert fibroblast cells into induced pluripotent stem (iPS) cells (Takahashi and Yamanaka 2006). Similar to iPS cells, CSCs can also self-renew and differentiate. Oct4, c-Myc, Nanog, and Klf4 were also identified as critical regulators in the maintenance of CSC self-renewal (Lee et al. 2011; Tseng et al. 2014; Zhu et al. 2015a). Some TFs involved in development are also required for the maintenance of CSCs, including Zic2, Notch2, and so on (Zhu et al. 2015a, b).

In fact, tumorigenesis is a process of oncogenic reprogramming, and many chromatin remodeling complexes are dysregulated in cancer cells and CSCs (Wang et al. 2007). As a driver factor in tumorigenesis, the chromatin remodeling becomes a critical target for cancer and CSC elimination (Jones and Baylin 2007). It has been reported that the SWI/SNF complex is involved in oncogenic reprogramming and CSC selfrenewal (Klochendler-Yeivin et al. 2002). The SWI/SNF complex can be formed into BRG1-contained SWI/SNF complex and BRM-contained SWI/SNF complex. The BRG1-contained SWI/SNF complex is increased in liver tumorigenesis, whereas the BRM-contained SWI/SNF complex is decreased. This switch between BRG1- and BRM-contained SWI/SNF complex plays a critical role in 
liver tumorigenesis and liver CSC self-renewal (Zhu et al. 2016b). The mutation of ARID1A, a component of SWI/SNF complex, also plays an important role in liver tumorigenesis and bladder tumorigenesis, and drives the self-renewal of liver CSCs and bladder CSCs as well (Fujimoto et al. 2012; Yang et al. 2017).

Many components of PRC2 complex are frequently mutated in various tumors. EZH2 is the core component of PRC2 and highly expressed in many solid tumors (Takawa et al. 2011). EZH2 depletion results in decreased breast CSCs and liver CSCs (Kleer et al. 2003; Zhu et al. 2016a). In contract, EZH2 loss of function mutation also drives tumorigenesis in acute lymphoblastic leukemia (Ntziachristos et al. 2014). Of note, EZH2 also promotes CSC self-renewal through a PRC2independent manner. Xu et al. revealed that the oncogenic role of EZH2 in prostatic cancer is PRC2independent (Xu et al. 2012). The non-classic role of EZH2 was validated in glioblastoma CSCs and liver CSCs, in which EZH2 exerts its role through STAT3 and $\beta$-catenin methylation (Kim et al. 2013; Zhu et al. 2016a). PRC1 complex is also involved in tumorigenesis, and the expression of its component BMI1 is related to the prognosis of many kinds of tumors (Laugesen and Helin 2014). BMI1 overexpressing head and neck squamous cell carcinoma showed enhanced metastasis and CSC-like characteristics (Yu et al. 2011).

The NURD complex is another critical remodeling complex that participates in the CSC self-renewal (Lai and Wade 2011). HDAC1 and HDAC2, two components of the NURD complex, are highly expressed in tumor patients with bad prognosis (West and Johnstone 2014). In many murine tumor models, HDAC1 and HDAC2 blockade inhibits tumor progress and CSC self-renewal (West and Johnstone 2014). However, the role of NURD complex in tumorigenesis and CSC self-renewal is controversial, depending on different components and tumor types. For example, HDAC1 and HDAC2 are highly expressed in breast cancer and promote tumor progresses, and LSD1 is lowly expressed in breast cancer and inhibits tumor progress (Lai and Wade 2011; Wang et al. 2009; West and Johnstone 2014). This inconsistency is also reflected by clinical applications. Although HDAC inhibitors inhibit tumor progress, some inhibitors may promote the propagation of certain tumors (Santoro et al. 2013).

Besides the SWI/SNF, PRC, and NURD complexes, some other chromatin remodeling complexes also participate in the tumorigenesis and CSC self-renewal. The NURF complex is highly expressed in liver cancer and liver CSCs, and drives the self-renewal of liver CSCs through OCT4 (Zhu et al. 2015a). Single-cell sequencing of bladder CSCs, non-CSCs, and normal bladder cells revealed that MLL2 promotes the self-renewal of bladder CSCs (Yang et al. 2017). Histone acetyltransferase MOZ and MORF are critical modulators for the selfrenewal of hematopoietic stem cells and leukemia CSCs (Yang and Ullah 2007).

Histone modification is also involved in the tumorigenesis and CSC self-renewal. In acute leukemia CSCs, H3K4me3 and H3K27me3 were enriched in the regions of CSC-associated genes (Yamazaki et al. 2013). The H3K4me3 levels in Oct4, Yap1, and TCF7 promoters are also related to the self-renewal of liver CSCs (Wang et al. 2015; Zhu et al. 2016a, b). Some modifications of histone variants are also related to the CSC self-renewal. The acetylation of H2A.Z (acH2A.Z) and methylation are involved in transcriptional repression of prostate cancer (Valdes-Mora et al. 2012). In addition to the modifications of specific regions, the total modification levels of H3K18ac and H3K4me2 are also correlated with prostate relapse, and the levels of H3K9ac, H3K18ac, H4K12ac, H4K16ac, H3K4me2, H4K20me3, and H4R3me2 are related to breast tumorigenesis as well (Elsheikh et al. 2009; Seligson et al. 2005).

Non-coding RNAs are also modulators for the CSC self-renewal, including microRNA, snoRNA (small nucleolar RNA), circRNA (circular RNA), IncRNA (long non-coding RNA), and so on. MicroRNA let-7 (Mir-let-7) is the first identified microRNA involved in CSC selfrenewal. Mir-let-7 is lowly expressed in breast CSCs, and inhibits the self-renewal of breast CSCs and breast tumorigenesis through H-Ras and HMGA2 (Yu et al. 2007). Mir-200c is another lowly expressed microRNA in breast CSCs, and suppresses breast CSC self-renewal through BMI expression (Shimono et al. 2009). Moreover, Mir-200c also participates in cell-fate decision of breast CSCs and non-CSCs (Shimono et al. 2009). In addition, Mir-34a inhibits the self-renewal of prostatic CSCs and prostatic cancer metastasis (Liu et al. 2011). Mir-181 is a modulator for the self-renewal of liver CSCs (Ji et al. 2009).

LncRNAs emerge as critical modulators in tumorigenesis and CSC self-renewal. MALAT-1 is highly expressed in pancreatic cancer and pancreatic CSCs, and its expression confers pancreatic cancer cell stem-like characteristics (Jiao et al. 2015). PVT1 is copy-number gained in various tumors, accompanied with PVT1 overexpression, which promotes the stability of c-Myc and thus initiates tumorigenesis and CSC self-renewal (Tseng et al. 2014). Fan lab identified several lncRNAs in liver CSCs that are involved in their self-renewal maintenance (Fig. 1). LncTCF7 is highly expressed in liver CSCs and required for the self-renewal of liver CSCs. Mechanistically, LncTCF7 recruits the SWI/SNF complex to initiate TCF7 expression and subsequently initiates 


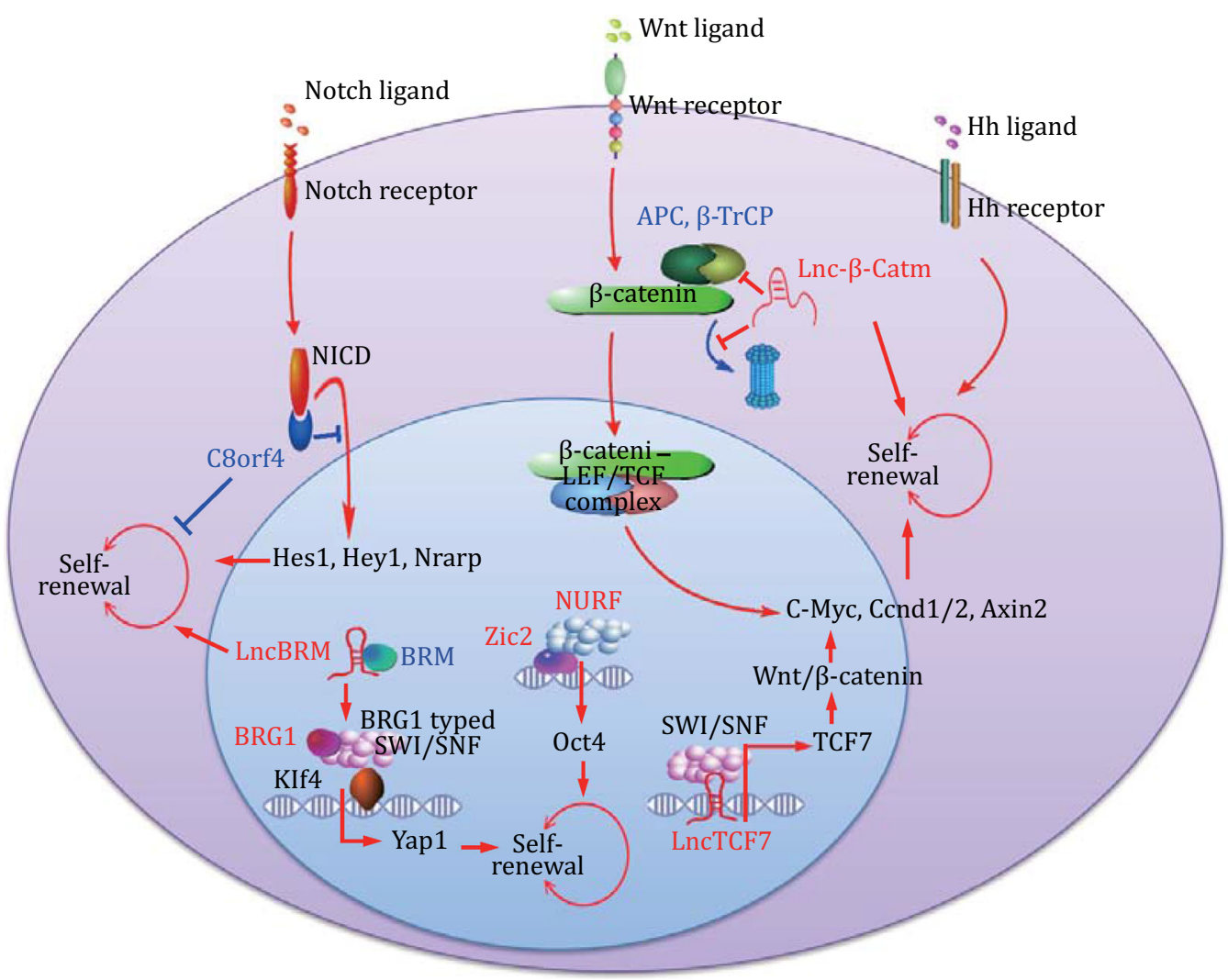

Fig. 1 Newly identified modulators of liver CSC self-renewal. LncTCF7, lnc- $\beta$-catm, lncBRM, C8orf4, and Zic2 were identified as critical liver CSC regulators by Fan lab (Hermann et al. 2007; Takawa et al. 2011; Yang et al. 2008a, b; Zhu et al. 2015a, b, 2016a, b). The newly identified positive regulators are shown in red and negative regulators in blue

Wnt/ $\beta$-catenin activation (Wang et al. 2015). Lnc$\beta$-catm promotes the interaction between $\beta$-catenin and EZH2, which further methylates $\beta$-catenin and promotes its stability, leading to $\mathrm{Wnt} / \beta$-catenin signaling activation in liver CSCs (Zhu et al. 2016a). LncBRM binds specifically to BRM, but not BRG1, promoting the assembly of BRG1-contained SWI/SNF complex. The BRG1-contained SWI/SNF complex further initiates Yap1 signaling and finally sustains the liver CSC selfrenewal (Zhu et al. 2016b). Guarnerio et al. found many fused circular RNAs in leukemia drive leukemia tumorigenesis together with oncogenes (Guarnerio et al. 2016). Finally, sno-IncRNA SLERT can promote the transcription activity of ribosome RNA and initiates tumorigenesis (Xing et al. 2017).

Many genetic and epigenetic modulators have been identified in the regulation of CSC self-renewal; however, the precise regulatory mechanisms of CSC are still elusive. Some genome-scaled unbiased screening technologies, including shRNA screening, CRISPR screening, and CRISPRi screening, have been widely used to identify functional genes (Liu et al. 2017; Shalem et al. 2014). To our knowledge, similar screenings have not been used for CSC research, and we believe that many potential modulators will be identified in the near future by using these functional screening techniques.

\section{CSC NICHES}

CSCs reside in their niches, which sustain the selfrenewal of CSCs and triggers tumorigenesis. The CSC niche contains niche cells and cytokines, and can be divided into inflammatory niche, perivascular niche, premetastatic niche, extracellular matrix, and neighboring cells.

In the inflammatory niche, tumor-associated macrophages and $\mathrm{CD}_{4}^{+}{ }^{+} \mathrm{T}$ cells secrete TNF $\alpha$ and activate NF$\kappa \mathrm{B}$ signaling of CSCs to induce expression of Slug, Snail, and Twist, and consequently drive epithelialmesenchymal transition (EMT) and CSC self-renewal (Liu et al. 2017).

The location of CSCs in tumor bulk has been an important issue for a long time. The CSCs were first observed to be located near from blood vessels. Head CSCs were found to be in contact with vascular endothelial cells directly, and the number of CSCs is related to vascular intensity (Calabrese et al. 2007). 
When co-cultured with vascular endothelial cells, CSCs form oncospheres 5-fold as large as CSCs alone (Calabrese et al. 2007). Neurospoagioma CSCs also reside near from blood vessels, where are supported by vesselderived Hedgehog, Notch, and PI3K molecules (Charles et al. 2010). The perivascular niche protects CSCs from radiation-induced damage, and initiates the self-renewal of CSCs (Charles et al. 2010). Meanwhile, vascular endothelial cells sustain the self-renewal of CSCs through the VEGF-Nrp1 signaling pathway (Beck et al. 2011).

Hypoxia is a typical characteristic of tumors and also serves as CSC niches. Hypoxia drives the self-renewal of CSCs through ROS and TGF $\beta$ signaling, and also protects CSCs from drug-induced and radiation-induced cell death (Scheel et al. 2011). Hypoxia-induced factor $1 \alpha$ (HIF1 $\alpha$ ) directly activates Notch signaling and thus drives CSC self-renewal in many solid tumors (Quail et al. 2012). HIF1 $\alpha$ also keeps CSCs in a quiescent state, reduces DNA damage, and finally maintains the selfrenewal of CSCs.

CSCs in primary locus and metastasis locus share similar transcription landscapes. There are also large similarity between CSCs and circulating tumor cells, which are critical for tumor metastasis. In addition, circulating tumor cells highly expressing CSC markers were also identified recently. These observations proved the relationship between CSCs and tumor metastasis (Yachida et al. 2010). The premetastatic niche contains six characteristics, including immune repression, inflammation, angiogenesis, lymphangiogenesis, organotropism, and reprogramming, which drives tumor metastasis and CSC self-renewal (Liu and Cao 2016). Moreover, the premetastatic niche also contains abundant vessels, niche cells, and factors, which support the survival and plasticity of CSCs (Takebe et al. 2011). In the lung metastasis of breast cancer, CSCs can induce periostin expression in lung fibroblast, which further drives the self-renewal of CSCs through engaging with Wnt ligands (Kitamura et al. 2015).

There are various kinds of cells near from CSCs, which support CSC self-renewal with nutrition and cytokines (Fig. 2). Mesenchymal stem cells (MSCs), cancer-associated fibroblasts (CAFs), tumor-associated macrophages (TAMs), and non-stem cancer cells play critical roles in the maintenance of CSC self-renewal. MSCs are multiple functional cells and can secrete many cytokines to promote the CSC self-renewal. MSCs can activate NF- $\kappa B$ signaling and drive CSC self-renewal by secreting CSCL12, IL-6, and IL-8 as well. Meanwhile, MSCs also secrete BMP antagonists to sustain CSCs in an undifferentiated state (Davis et al. 2015). In breast cancer, MSCs induce Mir-199a expression in cancer

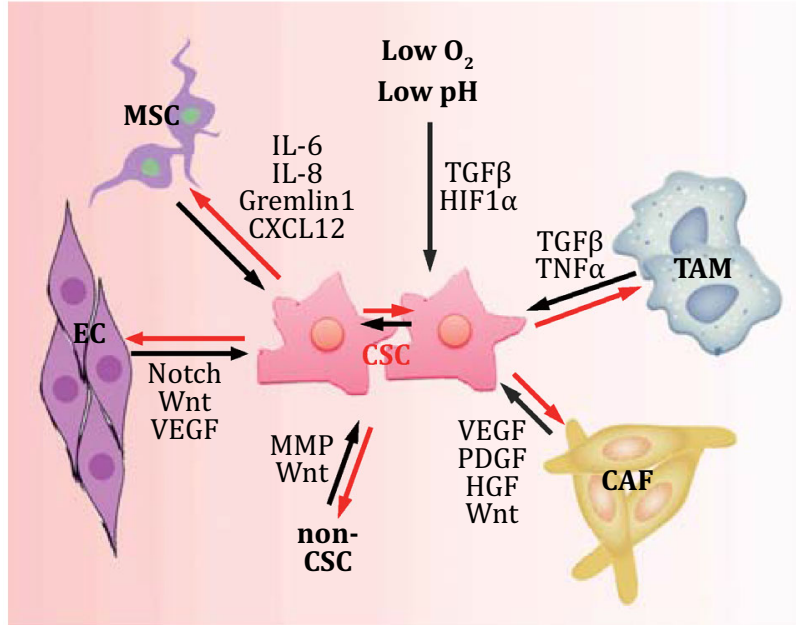

Fig. 2 Mutual interactions between CSCs and CSC niches. Main niche cells and factors for CSC self-renewal are shown. CSC: cancer stem cell, TAM: tumor-associated macrophage, CAF: cancerassociated fibroblast, MSC: mesenchymal stem cells, EC: endothelial cells

cells, which further inhibits FoxP2 expression and drives CSC self-renewal (Cuiffo et al. 2014). In tumors, endothelial cells and CSCs can convert fibroblasts to CAFs. CAFs secrete extracellular matrix, including VEGF, PDGF, HGF, and CXCL12, which drive the activation of Wnt and Notch signaling pathways for the self-renewal maintenance of CSCs (Kalluri and Zeisberg 2006). CAFs also remodel extracellular matrix, promote EMT, and drive CSC self-renewal through secreting metalloproteases such as MMP2, MMP3, and MMP9. Recently, Song lab identified a new subgroup of CAFs termed CD $10^{+} \mathrm{GPR}^{+} 7^{+} \mathrm{CAFs}$, which secrete IL-6 and IL-8 to activate $\mathrm{NF}-\kappa \mathrm{B}$ signaling in $\mathrm{CSCs}$, and consequently promote the propagation of breast cancer and lung cancer, drug resistance, and CSC self-renewal (Su et al. 2018). In addition, CSCs recruit macrophages, medullary precursor cells and MSCs to form a paracrine niche, which maintains the self-renewal of CSCs as well.

\section{TARGETING STRATEGIES AGAINST CSCS AND FUTURE CHALLENGES}

CSCs are considered as the origin of tumorigenesis, metastasis, drug resistance, and relapse. CSCs are in quiescent state and survive in response to many drugs that target tumor propagation (Kurtova et al. 2015). Meanwhile, CSCs can pump drugs out of cells owing to high-expression drug-pump molecules. Especially, CSCs can escape from drug-induced cell death. Unlike many tumor cells, CSCs efficiently escape from anoikis, which 
is prerequisite for tumor metastasis (Kreso and Dick 2014). During withdrawal of drugs, survived CSCs can propagate and differentiate into a new tumor. Therefore, targeting CSCs is a big challenge for tumor elimination.

As mentioned above, many surface markers of CSCs have been identified, and these markers become first choices for CSC targeting. CD13 antibody targeting liver CSCs can efficiently eliminate liver CSCs (Haraguchi et al. 2010). BCMab1 antibody targeting bladder CSC surface marker Integrin $\alpha 3 \beta 1$ can inhibit the selfrenewal of bladder CSCs and effectively suppress bladder cancer propagation (Li et al. 2014). Some important membrane proteins also serve as targets for CSC elimination. Rspo3 is highly expressed in colorectal cancer and plays a critical role in the self-renewal of intestinal stem cells and colorectal CSCs, and its blockade antibody has effective intervention on colorectal CSCs and colorectal tumors (Storm et al. 2016). The Wnt/ $\beta$ catenin, Hedgehog, Notch, BMP, and Pten pathways are also used as targets for CSC elimination, and the inhibitors of these signaling pathways can repress the CSC self-renewal. Although CSCs resist to traditional radiotherapy and chemotherapy, they are sensitive to certain therapies. For example, rapamycin, an inhibitor of mTOR signaling pathway, can eliminate CSCs of PTEN-deficient leukemia (Yilmaz et al. 2006). G-CSF treatment on ALL CSCs can promote entrance of cell cycle, and thus increase the sensitivity of ALL CSCs to chemotherapy (Kreso and Dick 2014). Finally, BMP4 can convert glioma CSCs into normal glia cells (Gargiulo et al. 2013).

Targeting CSC niches emerges as a new therapy for CSC clearance. HIF1 $\alpha$ and HIF $2 \alpha$ are good targets for glioma and glioma CSCs (Soeda et al. 2009). VEGF targeting antibody Bevacizumab suppresses the selfrenewal of CSCs and effectively inhibits tumor propagation and metastasis (Ye et al. 2014). Inhibition of CCR2 and M-CSF in pancreatic cancer decreases the numbers of macrophages and CSCs (Mitchem et al. 2013). The antibody against fibronectin receptor Integrin $\alpha 4 \beta 1$ inhibits the protection of CSCs resisting to chemotherapy (Kaplan et al. 2005). Moreover, CSCs can also serve as a target for immunotherapy, a promising therapy for tumor treatment (Codd et al. 2018).

However, many CSC markers are also the markers of normal tissue stem cells and progenitor cells. For instance, LGR5, a marker of colorectal CSC, is also a marker of intestinal stem cells (Barker et al. 2007). CD133 and CD44 are CSC markers in many tumors, and they are also markers of many tissue progenitor cells. Wnt/ß-catenin, Notch, and Hedgehog pathways not only participate in the self-renewal of CSCs, but also play critical roles in the maintenance modulation of normal tissue stem cells (Yang et al. 2008a). With the development of modern methodology, some specific markers for CSCs must be identified and can be used for CSC targeting in the future.

The heterogeneity of CSCs themselves is another challenge for CSC targeting. CSCs also contain various subgroups of cells according to singe cell sequencing and experimental data. Fan lab revealed a multiple origin of bladder CSCs through single-cell sequencing (Yang et al. 2017). Several markers of CSCs have been identified for a certain tumor type (Wang et al. 2015). CSC heterogeneity surely increases the difficulty for CSC targeting. Identifying all CSC subsets using single-cell RNA sequencing is needed for the study of CSC biology. In addition, the plasticity of CSCs is another layer difficulty for CSC targeting. CSCs have plastic capacity, and non-CSCs can transdifferentiate into CSCs once the primary CSCs are eliminated. Moreover, the newly formed CSCs can be also resistant to CSC-targeted therapies. As maintained above, targeting tumor cells with chemotherapy leads to the emerging of drug-resistant tumor cells derived from CSCs, and similarly, targeting CSCs can induce therapy-resistant CSCs due to non-CSC dedifferentiation. Therefore, the switch between CSCs and non-CSCs implies the necessity of combination of CSC-targeted therapy with traditional therapy together.

Acknowledgements This work was supported by the funding provided by the National Natural Science Foundation of China (91640203, 31771638), Beijing Natural Science Foundation (7181006), and Postdoctoral Innovative Talent Support Program to Pingping Zhu.

\section{Compliance with Ethical Standards}

Conflict of interest Pingping Zhu and Zusen Fan declare that they have no conflict of interest.

Human and animal rights and informed consent This article does not contain any studies with human or animal subjects performed by any of the authors.

Open Access This article is distributed under the terms of the Creative Commons Attribution 4.0 International License (http:// creativecommons.org/licenses/by/4.0/), which permits unrestricted use, distribution, and reproduction in any medium, provided you give appropriate credit to the original author(s) and the source, provide a link to the Creative Commons license, and indicate if changes were made.

\section{References}

Barker N, van Es JH, Kuipers J, Kujala P, van den Born M, Cozijnsen M, Haegebarth A, Korving J, Begthel H, Peters PJ, Clevers H (2007) Identification of stem cells in small intestine and colon by marker gene Lgr5. Nature 449:1003-1007

Barker N, Ridgway RA, van Es JH, van de Wetering M, Begthel $\mathrm{H}$, van den Born M, Danenberg E, Clarke AR, Sansom OJ, Clevers 
H (2009) Crypt stem cells as the cells-of-origin of intestinal cancer. Nature 457:608-611

Barry ER, Morikawa T, Butler BL, Shrestha K, de la Rosa R, Yan KS, Fuchs CS, Magness ST, Smits R, Ogino S, Kuo CJ, Camargo FD (2013) Restriction of intestinal stem cell expansion and the regenerative response by YAP. Nature 493:106-110

Beck B, Driessens G, Goossens S, Youssef KK, Kuchnio A, Caauwe A, Sotiropoulou PA, Loges S, Lapouge G, Candi A, Mascre G, Drogat B, Dekoninck S, Haigh JJ, Carmeliet P, Blanpain C (2011) A vascular niche and a VEGF-Nrp1 loop regulate the initiation and stemness of skin tumours. Nature 478:399-403

Calabrese C, Poppleton H, Kocak M, Hogg TL, Fuller C, Hamner B, Oh EY, Gaber MW, Finklestein D, Allen M, Frank A, Bayazitov IT, Zakharenko SS, Gajjar A, Davidoff A, Gilbertson RJ (2007) A perivascular niche for brain tumor stem cells. Cancer Cell 11:69-82

Cao L, Zhou Y, Zhai B, Liao J, Xu W, Zhang R, Li J, Zhang Y, Chen L, Qian H, Wu M, Yin Z (2011) Sphere-forming cell subpopulations with cancer stem cell properties in human hepatoma cell lines. BMC Gastroenterol 11:71

Chaffer CL, Weinberg RA (2015) How does multistep tumorigenesis really proceed? Cancer Discov 5:22-24

Charles N, Ozawa T, Squatrito M, Bleau AM, Brennan CW, Hambardzumyan D, Holland EC (2010) Perivascular nitric oxide activates notch signaling and promotes stem-like character in PDGF-induced glioma cells. Cell Stem Cell 6:141-152

Chiba T, Kita K, Zheng YW, Yokosuka O, Saisho H, Iwama A, Nakauchi H, Taniguchi H (2006) Side population purified from hepatocellular carcinoma cells harbors cancer stem celllike properties. Hepatology 44:240-251

Clevers H (2006) Wnt/beta-catenin signaling in development and disease. Cell 127:469-480

Codd AS, Kanaseki T, Torigo T, Tabi Z (2018) Cancer stem cells as targets for immunotherapy. Immunology 153:304-314

Cuiffo BG, Campagne A, Bell GW, Lembo A, Orso F, Lien EC, Bhasin MK, Raimo M, Hanson SE, Marusyk A, El-Ashry D, Hematti P, Polyak K, Mechta-Grigoriou F, Mariani O, Volinia S, VincentSalomon A, Taverna D, Karnoub AE (2014) MSC-regulated microRNAs converge on the transcription factor FOXP2 and promote breast cancer metastasis. Cell Stem Cell 15:762-774

Davis H, Irshad S, Bansal M, Rafferty H, Boitsova T, Bardella C, Jaeger E, Lewis A, Freeman-Mills L, Giner FC, RodenasCuadrado P, Mallappa S, Clark S, Thomas H, Jeffery R, Poulsom R, Rodriguez-Justo M, Novelli M, Chetty R, Silver A, Sansom OJ, Greten FR, Wang LM, East JE, Tomlinson I, Leedham SJ (2015) Aberrant epithelial GREM1 expression initiates colonic tumorigenesis from cells outside the stem cell niche. Nat Med 21:62-70

Dean M, Fojo T, Bates S (2005) Tumour stem cells and drug resistance. Nat Rev Cancer 5:275-284

Elsheikh SE, Green AR, Rakha EA, Powe DG, Ahmed RA, Collins HM, Soria D, Garibaldi JM, Paish CE, Ammar AA, Grainge MJ, Ball GR, Abdelghany MK, Martinez-Pomares L, Heery DM, Ellis IO (2009) Global histone modifications in breast cancer correlate with tumor phenotypes, prognostic factors, and patient outcome. Cancer Res 69:3802-3809

Fujimoto A, Totoki Y, Abe T, Boroevich KA, Hosoda F, Nguyen HH, Aoki M, Hosono N, Kubo M, Miya F, Arai Y, Takahashi H, Shirakihara T, Nagasaki M, Shibuya T, Nakano K, WatanabeMakino K, Tanaka H, Nakamura H, Kusuda J, Ojima H, Shimada K, Okusaka T, Ueno M, Shigekawa Y, Kawakami Y, Arihiro K, Ohdan H, Gotoh K, Ishikawa O, Ariizumi S, Yamamoto M, Yamada T, Chayama K, Kosuge T, Yamaue H, Kamatani N, Miyano S, Nakagama H, Nakamura Y, Tsunoda T, Shibata T, Nakagawa H (2012) Whole-genome sequencing of liver cancers identifies etiological influences on mutation patterns and recurrent mutations in chromatin regulators. Nat Genet 44:760-764

Gao X, Cui Y, Levenson RM, Chung LW, Nie S (2004) In vivo cancer targeting and imaging with semiconductor quantum dots. Nat Biotechnol 22:969-976

Gargiulo G, Cesaroni M, Serresi M, de Vries N, Hulsman D, Bruggeman SW, Lancini C, van Lohuizen M (2013) In vivo RNAi screen for BMI1 targets identifies TGF-beta/BMP-ER stress pathways as key regulators of neural- and malignant glioma-stem cell homeostasis. Cancer Cell 23:660-676

Gopalan V, Islam F, Lam AK (2018) Surface markers for the identification of cancer stem cells. Methods Mol Biol 1692:17-29

Greaves M (2013) Cancer stem cells as 'units of selection'. Evol Appl 6:102-108

Guarnerio J, Bezzi M, Jeong JC, Paffenholz SV, Berry K, Naldini MM, Lo-Coco F, Tay Y, Beck AH, Pandolfi PP (2016) Oncogenic role of fusion-circRNAs derived from cancer-associated chromosomal translocations. Cell 166:1055-1056

Haraguchi N, Ishii H, Mimori K, Tanaka F, Ohkuma M, Kim HM, Akita H, Takiuchi D, Hatano H, Nagano H, Barnard GF, Doki Y, Mori M (2010) CD13 is a therapeutic target in human liver cancer stem cells. J Clin Invest 120:3326-3339

Henderson T, Chen M, Darrow MA, Li CS, Chiu CL, Monjazeb AM, Murphy WJ, Canter RJ (2018) Alterations in cancer stem-cell marker CD44 expression predict oncologic outcome in softtissue sarcomas. J Surg Res 223:207-214

Hermann PC, Huber SL, Herrler T, Aicher A, Ellwart JW, Guba M, Bruns CJ, Heeschen C (2007) Distinct populations of cancer stem cells determine tumor growth and metastatic activity in human pancreatic cancer. Cell Stem Cell 1:313-323

Ji JF, Yamashita T, Budhu A, Forgues M, Jia HL, Li CL, Deng CX, Wauthier E, Reid LM, Ye QH, Qin LX, Yang W, Wang HY, Tang ZY, Croce CM, Wang XW (2009) Identification of microRNA181 by genome-wide screening as a critical player in EpCAM-positive hepatic cancer stem cells. Hepatology 50:472-480

Jiao F, Hu H, Han T, Yuan C, Wang L, Jin Z, Guo Z, Wang L (2015) Long noncoding RNA MALAT-1 enhances stem cell-like phenotypes in pancreatic cancer cells. Int J Mol Sci 16:6677-6693

Jones PA, Baylin SB (2007) The epigenomics of cancer. Cell 128:683-692

Kalluri R, Zeisberg M (2006) Fibroblasts in cancer. Nat Rev Cancer 6:392-401

Kaplan RN, Riba RD, Zacharoulis S, Bramley AH, Vincent L, Costa C, MacDonald DD, Jin DK, Shido K, Kerns SA, Zhu Z, Hicklin D, Wu Y, Port JL, Altorki N, Port ER, Ruggero D, Shmelkov SV, Jensen KK, Rafii S, Lyden D (2005) VEGFR1-positive haematopoietic bone marrow progenitors initiate the premetastatic niche. Nature 438:820-827

Katoh Y, Katoh M (2006) Hedgehog signaling pathway and gastrointestinal stem cell signaling network (Review). Int J Mol Med 18:1019-1023

Kim E, Kim M, Woo DH, Shin Y, Shin J, Chang N, Oh YT, Kim H, Rheey J, Nakano I, Lee C, Joo KM, Rich JN, Nam DH, Lee J (2013) Phosphorylation of EZH2 activates STAT3 signaling via STAT3 methylation and promotes tumorigenicity of glioblastoma stem-like cells. Cancer Cell 23:839-852

Kitamura T, Qian BZ, Pollard JW (2015) Immune cell promotion of metastasis. Nat Rev Immunol 15:73-86

Kleer CG, Cao Q Varambally S, Shen RL, Ota L, Tomlins SA, Ghosh D, Sewalt RGAB, Otte AP, Hayes DF, Sabel MS, Livant D, Weiss SJ, Rubin MA, Chinnaiyan AM (2003) EZH2 is a marker of aggressive breast cancer and promotes neoplastic 
transformation of breast epithelial cells. Proc Natl Acad Sci USA 100:11606-11611

Klochendler-Yeivin A, Muchardt C, Yaniv M (2002) SWI/SNF chromatin remodeling and cancer. Curr Opin Genet Dev 12:73-79

Kopan R, Ilagan MXG (2009) The canonical notch signaling pathway: unfolding the activation mechanism. Cell 137:216-233

Korinek V, Barker N, Morin PJ, van Wichen D, de Weger R, Kinzler KW, Vogelstein B, Clevers H (1997) Constitutive transcriptional activation by a beta-catenin-Tcf complex in $\mathrm{APC}^{-/-}$ colon carcinoma. Science 275:1784-1787

Krebs ET (1947) Cancer and the embryonal hypothesis. Calif Med 66:270-271

Kreso A, Dick JE (2014) Evolution of the cancer stem cell model. Cell Stem Cell 14:275-291

Kurtova AV, Xiao J, Mo Q Pazhanisamy S, Krasnow R, Lerner SP, Chen F, Roh TT, Lay E, Ho PL, Chan KS (2015) Blocking PGE2induced tumour repopulation abrogates bladder cancer chemoresistance. Nature 517:209-213

Lai AY, Wade PA (2011) Cancer biology and NuRD: a multifaceted chromatin remodelling complex. Nat Rev Cancer 11:588-596

Laugesen A, Helin K (2014) Chromatin repressive complexes in stem cells, development, and cancer. Cell Stem Cell 14:735-751

Lee TKW, Castilho A, Cheung VCH, Tang $\mathrm{KH}$, Ma S, Irene OLN (2011) CD24(+) liver tumor-initiating cells drive self-renewal and tumor initiation through STAT3-mediated NANOG regulation. Cell Stem Cell 9:50-63

Levina VV, Marrangoni A, Wang TT, Parikh S, Su YY, Herberman R, Lokshin A, Gorelik E (2010) Elimination of human lung cancer stem cells through targeting of the SCF-c-kit autocrine signaling loop. Cancer Res 70:4272

Li HX, Gao QL, Guo LP, Lu SH (2011) The PTEN/PI3K/Akt pathway regulates stem-like cells in primary esophageal carcinoma cells. Cancer Biol Ther 11:950-958

Li C, Yang Z, Du Y, Tang H, Chen J, Hu D, Fan Z (2014) BCMab1, a monoclonal antibody against aberrantly glycosylated integrin $\alpha 3 \beta 1$, has potent antitumor activity of bladder cancer in vivo. Clin Cancer Res 20:4001-4013

Li C, Du Y, Yang Z, He L, Wang Y, Hao L, Ding M, Yan R, Wang J, Fan Z (2016) GALNT1-mediated glycosylation and activation of sonic Hedgehog signaling maintains the self-renewal and tumor-initiating capacity of bladder cancer stem cells. Cancer Res 76:1273-1283

Li WZ, Ma HL, Zhang J, Zhu L, Wang C, Yang YL (2017) Unraveling the roles of CD44/CD24 and ALDH1 as cancer stem cell markers in tumorigenesis and metastasis. Sci Rep. https:// doi.org/10.1038/s41598-017-14364-2

Liu Y, Cao X (2016) Characteristics and significance of the premetastatic niche. Cancer Cell 30:668-681

Liu C, Kelnar K, Liu B, Chen X, Calhoun-Davis T, Li H, Patrawala L, Yan $\mathrm{H}$, Jeter $\mathrm{C}$, Honorio S, Wiggins JF, Bader AG, Fagin R, Brown D, Tang DG (2011) The microRNA miR-34a inhibits prostate cancer stem cells and metastasis by directly repressing CD44. Nat Med 17:211-215

Liu SJ, Horlbeck MA, Cho SW, Birk HS, Malatesta M, He D, Attenello FJ, Villalta JE, Cho MY, Chen Y, Mandegar MA, Olvera MP, Gilbert LA, Conklin BR, Chang HY, Weissman JS, Lim DA (2017) CRISPRi-based genome-scale identification of functional long noncoding RNA loci in human cells. Science. https://doi.org/10.1126/science.aah7111

MacDonald BT, Tamai K, He X (2009) Wnt/beta-catenin signaling: components, mechanisms, and diseases. Dev Cell 17:9-26

Marotta LLC, Almendro V, Marusyk A, Shipitsin M, Schemme J, Walker SR, Bloushtain-Qimron N, Kim JJ, Choudhury SA,
Maruyama R, Wu Z, Gönen M, Mulvey LA, Bessarabova MO, Huh SJ, Silver SJ, Kim SY, Park SY, Lee HE, Anderson KS, Richardson AL, Nikolskaya T, Nikolsky Y, Liu XS, Root DE, Hahn WC, Frank DA, Polyak K (2011) The JAK2/STAT3 signaling pathway is required for growth of CD44(+)CD24(-) stem cell-like breast cancer cells in human tumors. J Clin Invest 121:2723-2735

McGuire S (2016) World cancer report 2014. Geneva, Switzerland: World Health Organization, international agency for research on cancer, WHO Press, 2015. Adv Nutr 7:418-419

Meacham CE, Morrison SJ (2013) Tumour heterogeneity and cancer cell plasticity. Nature 501:328-337

Melo FS, Kurtova AV, Harnoss JM, Kljavin N, Hoeck JD, Hung J, Anderson JE, Storm EE, Modrusan Z, Koeppen H, Dijkgraaf GJ, Piskol R, de Sauvage FJ (2017) A distinct role for $\mathrm{Lgr}^{+}{ }^{+}$stem cells in primary and metastatic colon cancer. Nature 543:676-680

Merlos-Suarez A, Barriga FM, Jung P, Iglesias M, Cespedes MV, Rossell D, Sevillano M, Hernando-Momblona X, da Silva-Diz V, Munoz P, Clevers H, Sancho E, Mangues R, Batlle E (2011) The intestinal stem cell signature identifies colorectal cancer stem cells and predicts disease relapse. Cell Stem Cell 8:511-524

Mitchem JB, Brennan DJ, Knolhoff BL, Belt BA, Zhu Y, Sanford DE, Belaygorod L, Carpenter D, Collins L, Piwnica-Worms D, Hewitt S, Udupi GM, Gallagher WM, Wegner C, West BL, Wang-Gillam A, Goedegebuure P, Linehan DC, DeNardo DG (2013) Targeting tumor-infiltrating macrophages decreases tumor-initiating cells, relieves immunosuppression, and improves chemotherapeutic responses. Cancer Res 73:1128-1141

Mumm JS, Kopan R (2000) Notch signaling: from the outside in. Dev Biol 228:151-165

Ntziachristos P, Tsirigos A, Welstead GG, Trimarchi T, Bakogianni S, Xu L, Loizou E, Holmfeldt L, Strikoudis A, King B, Mullenders J, Becksfort J, Nedjic J, Paietta E, Tallman MS, Rowe JM, Tonon G, Satoh T, Kruidenier L, Prinjha R, Akira S, Van Vlierberghe P, Ferrando AA, Jaenisch R, Mullighan CG, Aifantis I (2014) Contrasting roles of histone 3 lysine 27 demethylases in acute lymphoblastic leukaemia. Nature 514:513-517

O'Brien CA, Pollett A, Gallinger S, Dick JE (2007) A human colon cancer cell capable of initiating tumour growth in immunodeficient mice. Nature 445:106-110

Organista-Nava J, Gomez-Gomez Y, Gariglio P (2014) Embryonic stem cell-specific signature in cervical cancer. Tumour Biol 35:1727-1738

Ponti D, Costa A, Zaffaroni N, Pratesi G, Petrangolini G, Coradini D, Pilotti S, Pierotti MA, Daidone MG (2005) Isolation and in vitro propagation of tumorigenic breast cancer cells with stem/progenitor cell properties. Cancer Res 65:5506-5511

Quail DF, Taylor MJ, Postovit LM (2012) Microenvironmental regulation of cancer stem cell phenotypes. Curr Stem Cell Res T 7:197-216

Ricci-Vitiani L, Lombardi DG, Pilozzi E, Biffoni M, Todaro M, Peschle C, De Maria R (2007) Identification and expansion of human colon-cancer-initiating cells. Nature 445:111-115

Santoro F, Botrugno OA, Dal Zuffo R, Pallavicini I, Matthews GM, Cluse L, Barozzi I, Senese S, Fornasari L, Moretti S, Altucci L, Pelicci PG, Chiocca S, Johnstone RW, Minucci S (2013) A dual role for Hdac1: oncosuppressor in tumorigenesis, oncogene in tumor maintenance. Blood 121:3459-3468

Scheel C, Eaton EN, Li SH, Chaffer CL, Reinhardt F, Kah KJ, Bell G, Guo W, Rubin J, Richardson AL, Weinberg RA (2011) Paracrine and autocrine signals induce and maintain mesenchymal and stem cell states in the breast. Cell 145:926-940

Schepers AG, Snippert HJ, Stange DE, van den Born M, van Es JH, van de Wetering $M$, Clevers $H$ (2012) Lineage tracing reveals 
$\operatorname{Lgr}^{+}$stem cell activity in mouse intestinal adenomas. Science 337:730-735

Schroeder A, Heller DA, Winslow MM, Dahlman JE, Pratt GW, Langer R, Jacks T, Anderson DG (2012) Treating metastatic cancer with nanotechnology. Nat Rev Cancer 12:39-50

Seligson DB, Horvath S, Shi T, Yu H, Tze S, Grunstein M, Kurdistani SK (2005) Global histone modification patterns predict risk of prostate cancer recurrence. Nature 435:1262-1266

Shabbir A, Esfandyari T, Farassati F (2018) Cancer stem cells, the ultimate targets in cancer therapy. OncoTargets Therapy 11:183-184

Shalem O, Sanjana NE, Hartenian E, Shi X, Scott DA, Mikkelson T, Heckl D, Ebert BL, Root DE, Doench JG, Zhang F (2014) Genome-scale CRISPR-Cas9 knockout screening in human cells. Science 343:84-87

Shigdar S, Lin J, Li Y, Yang CJ, Wei M, Zhus Y, Liu H, Duan W (2012) Cancer stem cell targeting: the next generation of cancer therapy and molecular imaging. Ther Deliv 3:227-244

Shimokawa M, Ohta Y, Nishikori S, Matano M, Takano A, Fujii M, Date S, Sugimoto S, Kanai T, Sato T (2017) Visualization and targeting of $\mathrm{LGR}^{+}$human colon cancer stem cells. Nature 545:187-192

Shimono Y, Zabala M, Cho RW, Lobo N, Dalerba P, Qian D, Diehn M, Liu H, Panula SP, Chiao E, Dirbas FM, Somlo G, Pera RA, Lao K, Clarke MF (2009) Downregulation of miRNA-200c links breast cancer stem cells with normal stem cells. Cell 138:592-603

Soeda A, Park M, Lee D, Mintz A, Androutsellis-Theotokis A, McKay RD, Engh J, Iwama T, Kunisada T, Kassam AB, Pollack IF, Park DM (2009) Hypoxia promotes expansion of the CD133positive glioma stem cells through activation of HIF-1 alpha. Oncogene 28:3949-3959

Storm EE, e Melo FDS, Tremayne J, Kljavin N, Tan C, Ye X, Chiu C, Pham T, Hongo JA, Bainbridge T, Firestein R, Blackwood E, Metcalfe C, Stawiski EW, Yauch RL, Wu Y, de Sauvage FJ (2016) Targeting PTPRK-RSPO3 colon tumours promotes differentiation and loss of stem-cell function. Nature 529:97-100

Su SC, Chen JN, Yao HR, Liu J, Yu SB, Lao LY, Wang MH, Luo ML, Xing Y, Chen F, Huang D, Zhao J, Yang L, Liao D, Su F, Li M, Liu Q Song E (2018) CD10(+)GPR77(+) cancer-associated fibroblasts promote cancer formation and chemoresistance by sustaining cancer stemness. Cell 172:841-856

Sun TM, Wang YC, Wang F, Du JZ, Mao CQ, Sun CY, Tang RZ, Liu Y, Zhu J, Zhu YH, Yang XZ, Wang J (2014) Cancer stem cell therapy using doxorubicin conjugated to gold nanoparticles via hydrazone bonds. Biomaterials 35:836-845

Takahashi K, Yamanaka S (2006) Induction of pluripotent stem cells from mouse embryonic and adult fibroblast cultures by defined factors. Cell 126:663-676

Takawa M, Masuda K, Kunizaki M, Daigo Y, Takagi K, Iwai Y, Cho HS, Toyokawa G, Yamane Y, Maejima K, Field HI, Kobayashi T, Akasu T, Sugiyama M, Tsuchiya E, Atomi Y, Ponder BA, Nakamura Y, Hamamoto R (2011) Validation of the histone methyltransferase EZH2 as a therapeutic target for various types of human cancer and as a prognostic marker. Cancer Sci 102:1298-1305

Takebe N, Harris PJ, Warren RQ Ivy SP (2011) Targeting cancer stem cells by inhibiting Wnt, Notch, and Hedgehog pathways. Nat Rev Clin Oncol 8:97-106

Takebe N, Miele L, Harris PJ, Jeong W, Bando H, Kahn M, Yang SX, Ivy SP (2015) Targeting Notch, Hedgehog, and Wnt pathways in cancer stem cells: clinical update. Nat Rev Clin Oncol 12:445-464

Terstappen LW, Huang S, Safford M, Lansdorp PM, Loken MR (1991) Sequential generations of hematopoietic colonies derived from single nonlineage-committed $\mathrm{CD}^{+} 4^{+} \mathrm{CD}^{-} 8^{-}$ progenitor cells. Blood 77:1218-1227

Tseng YY, Moriarity BS, Gong W, Akiyama R, Tiwari A, Kawakami $\mathrm{H}$, Ronning P, Reuland B, Guenther K, Beadnell TC, Essig J, Otto GM, O'Sullivan MG, Largaespada DA, Schwertfeger KL, Marahrens Y, Kawakami Y, Bagchi A (2014) PVT1 dependence in cancer with MYC copy-number increase. Nature 512:82-86

Valdes-Mora F, Song JZ, Statham AL, Strbenac D, Robinson MD, Nair SS, Patterson KI, Tremethick DJ, Stirzaker C, Clark SJ (2012) Acetylation of H2A.Z is a key epigenetic modification associated with gene deregulation and epigenetic remodeling in cancer. Genome Res 22:307-321

Van der Flier LG, Haegebarth A, Stange DE, Van de Wetering M, Clevers H (2009) OLFM4 is a robust marker for stem cells in human intestine and marks a subset of colorectal cancer cells. Gastroenterology 137:15-17

Visvader JE, Lindeman GJ (2012) Cancer stem cells: current status and evolving complexities. Cell Stem Cell 10:717-728

Wang GG, Allis CD, Chi P (2007) Chromatin remodeling and cancer, part I: covalent histone modifications. Trends Mol Med 13:363-372

Wang Y, Zhang H, Chen YP, Sun YM, Yang F, Yu WH, Liang J, Sun LY, Yang XH, Shi L, Li R, Li Y, Zhang Y, Li Q Yi X, Shang Y (2009) LSD1 is a subunit of the NuRD complex and targets the metastasis programs in breast cancer. Cell 138:660-672

Wang Y, He L, Du Y, Zhu P, Huang G, Luo J, Yan X, Ye B, Li C, Xia P, Zhang G, Tian Y, Chen R, Fan Z (2015) The long noncoding RNA lncTCF7 promotes self-renewal of human liver cancer stem cells through activation of Wnt signaling. Cell Stem Cell 16:413-425

West AC, Johnstone RW (2014) New and emerging HDAC inhibitors for cancer treatment. J Clin Invest 124:30-39

Wu G, Xu GZ, Schulman BA, Jeffrey PD, Harper JW, Pavletich NP (2003) Structure of a beta-TrCP1-Skp1-beta-catenin complex: destruction motif binding and lysine specificity of the SCF beta-TrCP1 ubiquitin ligase. Mol Cell 11:1445-1456

Xing YH, Yao RW, Zhang Y, Guo CJ, Jiang S, Xu G, Dong R, Yang L, Chen LL (2017) SLERT regulates DDX21 rings associated with pol I transcription. Cell 169(664-678):e616

Xu K, Wu ZJ, Groner AC, He HH, Cai C, Lis RT, Wu X, Stack EC, Loda M, Liu T, Xu H, Cato L, Thornton JE, Gregory RI, Morrissey C, Vessella RL, Montironi R, Magi-Galluzzi C, Kantoff PW, Balk SP, Liu XS, Brown M (2012) EZH2 oncogenic activity in castration-resistant prostate cancer cells is polycombindependent. Science 338:1465-1469

Yachida S, Jones S, Bozic I, Antal T, Leary R, Fu B, Kamiyama M, Hruban RH, Eshleman JR, Nowak MA, Velculescu VE, Kinzler KW, Vogelstein B, Iacobuzio-Donahue CA (2010) Distant metastasis occurs late during the genetic evolution of pancreatic cancer. Nature 467:1114-1117

Yamazaki J, Estecio MR, Lu Y, Long H, Malouf GG, Graber D, Huo Y, Ramagli L, Liang S, Kornblau SM, Jelinek J, Issa JP (2013) The epigenome of AML stem and progenitor cells. Epigenetics 8:92-104

Yang XJ, Ullah M (2007) MOZ and MORF, two large MYSTic HATs in normal and cancer stem cells. Oncogene 26:5408-5419

Yang W, Yan HX, Chen L, Liu Q, He YQ Yu LX, Zhang SH, Huang DD, Tang L, Kong XN, Chen C, Liu SQ, Wu MC, Wang HY (2008a) Wnt/beta-catenin signaling contributes to activation of normal and tumorigenic liver progenitor cells. Cancer Res 68:4287-4295

Yang ZF, Ho DW, Ng MN, Lau CK, Yu WC, Ngai P, Chu PW, Lam CT, Poon RT, Fan ST (2008b) Significance of $\mathrm{CD}^{+} 0^{+}$cancer stem cells in human liver cancer. Cancer Cell 13:153-166

Yang L, Ren Y, Yu X, Qian F, Bian BSJ, Xiao HL, Wang WG, Xu SL, Yang J, Cui W, Liu Q, Wang Z, Guo W, Xiong G, Yang K, Qian C, 
Zhang X, Zhang P, Cui YH, Bian XW (2014) ALDH1A1 defines invasive cancer stem-like cells and predicts poor prognosis in patients with esophageal squamous cell carcinoma. Mod Pathol 27:775-783

Yang Z, Li C, Fan Z, Liu H, Zhang X, Cai Z, Xu L, Luo J, Huang Y, He L, Liu C, Wu S (2017) Single-cell sequencing reveals variants in ARID1A, GPRC5A and MLL2 driving self-renewal of human bladder cancer stem cells. Eur Urol 71:8-12

Ye J, Wu D, Wu P, Chen ZG, Huang J (2014) The cancer stem cell niche: cross talk between cancer stem cells and their microenvironment. Tumor Biol 35:3945-3951

Yilmaz $\mathrm{OH}$, Valdez R, Theisen BK, Guo W, Ferguson DO, Wu H, Morrison SJ (2006) Pten dependence distinguishes haematopoietic stem cells from leukaemia-initiating cells. Nature 441:475-482

Yu F, Yao H, Zhu P, Zhang X, Pan Q, Gong C, Huang Y, Hu X, Su F, Lieberman J, Song E (2007) Let-7 regulates self renewal and tumorigenicity of breast cancer cells. Cell 131:1109-1123

Yu CC, Lo WL, Chen YW, Huang PI, Hsu HS, Tseng LM, Hung SC, Kao SY, Chang CJ, Chiou SH (2011) BMI-1 regulates snail expression and promotes metastasis ability in head and neck squamous cancer-derived ALDH1 positive cells. J Oncol. https://doi.org/10.1155/2011/609259

Zheng H, Pomyen Y, Hernandez MO, Li C, Livak F, Tang W, Dang H, Greten TF, Davis JL, Zhao Y, Mehta M, Levin Y, Shetty J, Tran B,
Budhu A, Wang XW (2018) Single-cell analysis reveals cancer stem cell heterogeneity in hepatocellular carcinoma. Hepatology 68:127-140

Zhou JB, Wulfkuhle J, Zhang H, Gu PH, Yang YQ Deng JH, Margolick JB, Liotta LA, Petricoin E, Zhang Y (2007) Activation of the PTEN/mTOR/STAT3 pathway in breast cancer stem-like cells is required for viability and maintenance. Proc Natl Acad Sci USA 104:16158-16163

Zhu P, Wang Y, He L, Huang G, Du Y, Zhang G, Yan X, Xia P, Ye B, Wang S, Hao L, Wu J, Fan Z (2015a) ZIC2-dependent OCT4 activation drives self-renewal of human liver cancer stem cells. J Clin Invest 125:3795-3808

Zhu PP, Wang YY, Du Y, He L, Huang GL, Zhang G, Yan XL, Fan ZS (2015b) C8orf4 negatively regulates self-renewal of liver cancer stem cells via suppression of NOTCH2 signalling. Nat Commun 6:1722

Zhu P, Wang Y, Huang G, Ye B, Liu B, Wu J, Du Y, He L, Fan Z (2016a) lnc-beta-Catm elicits EZH2-dependent beta-catenin stabilization and sustains liver CSC self-renewal. Nat Struct Mol Biol 23:631-639

Zhu P, Wang Y, Wu J, Huang G, Liu B, Ye B, Du Y, Gao G, Tian Y, He L, Fan Z (2016b) LncBRM initiates YAP1 signalling activation to drive self-renewal of liver cancer stem cells. Nat Commun $7: 13608$ 